\title{
Entrepreneurial self-efficacy and entrepreneurial intention: The mediating role of the need for independence
}

\author{
Victor Osadolor ${ }^{1}$ (D) Emmanuel K. Agbaeze ${ }^{2}$ \\ Ejikeme Emmanuel Isichei ${ }^{3}$ \\ Samuel Taiwo Olabosinde ${ }^{4}$
}

\begin{abstract}
PURPOSE: The paper focuses on assessing the direct effect of entrepreneurial self-efficacy and entrepreneurial intention and the indirect effect of the need for independence on the relationship between the constructs. Despite increased efforts towards steering the interest of young graduates towards entrepreneurial venture, the response rate has been rather unimpressive and discouraging, thus demanding the need to account for what factors could drive intention towards venture ownership among graduates in Nigeria. METHODOLOGY: A quantitative approach was adopted and a data set from 235 graduates was used for the study. The data was analyzed using the partial least square structural equation model (PLS-SEM). FINDINGS: It was found that self-efficacy does not significantly affect intention. It was also found that the need for independence affects entrepreneurial intention. The study found that the need for independence fully mediates the relationship between entrepreneurial self-efficacy and entrepreneurial intention. PRACTICAL IMPLICATIONS: This paper provides new insight into the behavioral reasoning theory, through its application in explaining the cognitive role of the need for independence in decision-making, using samples from a developing economy. ORIGINALITY AND VALUE: The study advances a new perspective on the underlining factors that account for an entrepreneur's intent to start a business venture, most especially among young graduates in Nigeria, through the lens of the behavioral reasoning theory. We further support the

1 Victor Osadolor, Lecturer, Department of Business Administration, Edo State University, Uzairue, Nigeria, e-mail: osadolor.victor@edouniversity.edu.ng (ORCID ID: https://orcid.org/0000-0002-1116-9974).

2 Kalu Emmanuel Agbaeze, Professor of Entrepreneurship, Department of Management, University of Nigeria, Enugu, Nigeria, e-mail: emmanuel.agbaeze@unn.edu.ng (ORCID ID: https://orcid.org/0000-0002-8952-7612).

3 Ejikeme Emmanuel Isichei, Lecturer, Department of Business Administration, Federal University Wukari, Nigeria, e-mail: e.isichei@fuwukari.edu.ng (ORCID ID: https://orcid.org/0000-0002-3816-9958).

4 Samuel Taiwo Olabosinde, Lecturer, Department of Business Administration, Federal University Wukari, Nigeria, e-mail: olabosinde@yahoo.com (ORCID ID: https://orcid.org/0000-0002-3324-1674).
\end{abstract}


application of the theory in entrepreneurship literature, given the paucity of studies that have adopted the theory despite its relevance.

Keywords: self-efficacy, entrepreneurial intention, independence, self-belief, PLS-SEM

\section{INTRODUCTION}

Entrepreneurship has been advanced globally to be a viable instrument for sustained economic growth and development. This explains the current focus on entrepreneurship as a means through which economic growth and development, progress, employment generation, creativity, and improvement of a nation can be attained (Urbano \& Aparicio, 2015). Entrepreneurship is germane to economic development, the answer to joblessness and other societal issues. Hence, it is important to understand and account for factors that would steer its development in a country (Staniewski \& Awruk, 2015).

Scholars have opined that entrepreneurial activities depend on the intention to act in a certain manner. This means intention is a paramount determinant of action (Solesvik, 2013). Entrepreneurial intention (EI) has been described as not just a desire to start, but also as a sincere motivation and willingness to engage in an entrepreneurial venture. It has been said to be an essential element of entrepreneurship (Liñán \& Fayolle, 2015; Valencia, Montoya, \& Montoya, 2016), hence, making it necessary to account for the factors that could trigger the intent of individuals to engage in a venture of their own.

One major individual psychological trait that has attracted scholarly attention in the literature, and has been found to affect intention, is entrepreneurial self-efficacy (Miao, Qian, \& Ma, 2017; Newman et al., 2019). Entrepreneurial self-efficacy (ESE) denotes an individual's belief in deploying available resources, skills, and expertise to successfully accomplish or undertake a task (Torres \& Watson, 2013). The belief that a person has the right skills and expertise could make them start a business of their own. However, there have been inconsistencies in the findings on the link between ESE and El, as scholars have found divergent findings in the relationship (Densberger, 2014; Setiawan, 2013; Yurtkoru, Acar, \& Teraman, 2014; Zhao, Seibert, \& Hills, 2005), thus necessitating an investigation into other factors that could account for the inconsistencies in the findings.

Drawing on the behavioral reasoning theory, we proposed the need for independence as the mediating variable that accounts for the link between ESE and El. The desire for independence is mostly regarded as the foremost element of inspiration as to why individuals become entrepreneurs (Walter \& Block, 2016; Verheul, Thurik, Hessels, \& van der Zwan, 2010). The need 
for independence denotes having the ability to make your own decisions and manage your business yourself without external interference (Shava \& Chinyamurindi, 2019). The business climate in Nigeria offers little to young adults in terms of support towards venture creation. It thus implies that developing the need for independence as an entrepreneur could account for the process through which their self-belief is triggered towards steering the need to start, own and manage a venture.

Recent studies have accounted for a number of mediating variables in the link between ESE and EI (Arshad, Farooq, Sultana, \& Farooq, 2016; Pihie \& Bagneri, 2013; Tsai, Chang, \& Peng, 2016). However, there are few studies that have accounted for the role of the need for independence as a mediating variable. The need for independence is a strong internal persuasive pressure that steers the quest for control and achievement. As such, when ESE is channeled through it, there is a greater chance that it will lead to El. The motivation towards self-employment starts with the need for independence (Barba-Sánchez \& Atienza-Sahuquill, 2018). As such, this motivational reason could account for the extent to which one's self-confidence would affect one's intent to engage in a venture, irrespective of any perceived barriers.

Further, there have been calls for more research on ESE and intention, given the difficulty in drawing conclusions on intention and since entrepreneurial pursuits are created and evolving (Hsu, Wiklund, \& Cotton 2017; Phipps \& Prieto, 2015; Newman et al., 2019). While there have been studies that account for the link between ESE and El in postgraduate students (Douglas \& Fitzsimmons, 2013; Vanevenhoven \& Liguori, 2016), undergraduates (Pfeifer, Šarlija, \& Zekic Sušac, 2016; Horvath, 2016), and secondary school students (Sanchez, 2013), there has been a dearth of studies that account for this relationship among young graduates. It is necessary to close this gap given the fact that, when compared to actual entrepreneurs, the validity of these studies cannot be generalized. Hence, the need for a study that covers individuals with the educational and technical capacity to engage as entrepreneurs.

In Nigeria, there have been diverse government support efforts to see the development of an entrepreneurial mindset among young adults. The efforts are evident in the creation of agencies such as the small and medium enterprise development agency of Nigeria (SMEDAN), the national directorate of employment (NDE), the small and medium industries equity investment scheme (SMIEIS), and the development Bank of Nigeria (DBN). All were established to ensure entrepreneurship development within the country, but they have all contributed minimally to steering El among Nigerian graduates. Also, despite the introduction of entrepreneurship education for all levels of education, the number of start-ups among young graduates has remained unimpressive, with the unemployment rates rising continually. 
Thus, it makes one wonder what role self-belief would have in steering a graduate's intention towards starting a venture and what influence the need for independence would have in supporting a graduate's self-belief as a tool in advancing graduates' start-up intentions. This has become necessary owing to the growing rate of unemployment and the inability of the private sector to absorb the growing number of graduates in the country.

\section{THEORETICAL AND HYPOTHESES DEVELOPMENT}

There have been diverse models proposed to explain the behaviors and intentions of entrepreneurs. However, a major challenge with most of these theories is their inability to account, truly, for the reason for the behaviour or intention. The inability to account for the reason for behavior only limits the knowledge of a true inherent, intrinsic factor(s) that supports or negates a behavior or intention. Hence, the behavioral reasoning theory was adopted to explore the link between ESE and El in this paper.

The behavioral reasoning theory is concerned with the role of reason in explaining specific intentions. It seeks to explain the reason for and against an action (Westaby, Probst, \& Lee, 2010). The central premise of the theory is centered around its position that actions are not without in-depth complex reasoning processes, and it is necessary to have a good understanding of what might drive, positively or negatively, a course of action given their effect on the formation of intentions (Calza, Cannavale, \& Nadali, 2020).

The theory is rooted in the explanation and reason-based models, as it is believed that reasons are fundamental components of individuals' intentions (Ryan \& Casidy, 2018). It is the basis for individual actions and validates behaviors that are not entirely common to general evaluations (Westaby, 2005). Gigerenzer and Goldstein (1996) opined that, based on an individual's reasons, intentions can be formed almost immediately rather than undertaking general global motives before the individual takes a course of action. The reason is the foundation for individuals to believe that reason could trigger another course of outcome or action and that future behaviors can be premised on that reason (Westaby, 2005).

The theory concisely explains a comprehensive knowledge of behaviors because it takes into cognizance context-specific reasons that individuals adopt to justify and defend their behavior (Norman, Conner, \& Stride, 2012). The theory's adoption in entrepreneurial literature has been limited (Miralles, Giones, \& Gozun, 2017; Norman et al., 2012), but it has become increasingly necessary because it allows for explaining intention beyond the domain of self-belief by attempting to account for the reason for the self-belief. 
The application of this theory to this paper is based on our argument that the need for independence is the reason that accounts for young graduates' faith in their capacity to gather and utilize necessary assets, talents, and expertise towards engaging in entrepreneurial activities.

\section{Entrepreneurial self-efficacy and entrepreneurial intention}

Self-efficacy is when an individual has faith in his/her capacity to gather and utilize necessary assets, talents, and expertise to achieve or implement a job (Neneh, 2020). An individual with advanced self-efficacy will exert more effort over a longer period of time, and withstand all odds till they accomplish their goal, while setting complex objectives and establishing improved tactics and schemes for the job. An individual with self-efficacy has the capacity to accept disapproval in a more optimistic way (Torres \& Watson, 2013). Self-efficacy is germane in the entrepreneurship process, as the procedure requires much determination, perseverance, and preparation. ESE includes prospects that can be viewed as distinguishing and typical physiognomies of an entrepreneur (Ayodele, 2013).

Entrepreneurial self-efficacy denotes belief in one's own ability, which must be translated into genuine entrepreneurial task outcomes to impact an organization's performance (Torres \& Watson, 2013; Khedhaouria, Guru, \& Torrès, 2014). This means that the more an entrepreneur believes in his/her ability to complete an entrepreneurial task effectively, the more likely they are to galvanize their business venture to greater success. Individuals with higher ESE have a greater tendency to develop their intent to have control, achieve inspiring goals, and choose diverse tactics towards accomplishing them.

Kautonen, Gelderen, and Fink (2015) defined El as a person's drive to commence a commercial venture in which the inward drive serves as a favorable insight in commencing a commercial venture. It is an inward recognized persuasion by an individual that he or she should establish commercial outlets as well as carefully project to act accordingly at any point in time (Lorz \& Volery, 2011). Saeed, Yousafzai, Yani-De-Soriano, and Muffatto (2015) view entrepreneurship as the course of producing risks by which El develop the link amid the notion and the performance, ensuring the viability of an entrepreneurial process.

El means a resolution by a person to convert from joblessness or paid job to owning a business. The resolution to own a business is done with alertness, as it is deliberate and pre-meditated (Verheul, Thurik, Hessel, \& van der Zwan, 2010). Linan, Nabi, and Krueger (2013) defined El as a pre-meditated decision and resolution by a person to start an ingenious commercial outlet. The examination of El serves as a major clarification for the establishment 
of businesses, hence, the reason to explore elements that make individuals develop their intent to start their own business (Devonish, Alleyne, CharlesSoverall, Marshall, \& Pounder, 2010; Liñán \& Fayolle, 2015; Obschonka \& Rodermund, 2010; Valencia, Montoya, \& Montoya, 2016).

Since $\mathrm{El}$ is a purposeful action to engage in a venture, as such, an individual's self-appraisal of their ability to take advantage of an opportunity and convert it into venture creation would most likely drive their willingness to engage in the venture. An individual's belief in their ability to undertake a task drives their interest (Ayodele 2013), which is most likely to define the individual's decision to become an entrepreneur. When ESE drives El, there are greater chances for increased performance, most especially for small-scale ventures (Shinnar, Hsu, \& Powell, 2014). This is because the judgment and actions of the business's founder have a direct impact on the enterprise's direction and overall performance (Neneh, 2015). ESE facilitates the connection between tactical disposition and El and also coordinates the linkage between tactical disposition and increased entrepreneurial intent (Prabhu, McGuire, Drost, \& Kwong, 2012).

Self-efficacy determines an individual's capacity to attain a particular level of accomplishment. It is seen as an element that has a huge influence on El or the decision to become an entrepreneur because of an individual's confidence in their entrepreneurial capacity (Ayodele, 2013). ESE can also influence the type of venture in which an entrepreneur actively engages in, since the venture was borne out of interest that is triggered from the individuals self-belief in their ability; hence, there will be a greater propensity of perseverance that would aid in the creation of inspiring progress forecasts for the venture, and help in providing the consistency with which pressure is applied in order to meet pre-determined targets.

Further, since the self-belief is largely dependent on the individual's level of knowledge and expertise in that field, there is a greater tendency that it will steer the individual towards owning and managing a venture of their interest, which will allow the individual to apply their knowledge, gain new experience and explore their networks towards ensuring the sustainability of their venture.

Akhtar, Hongyuan, Iqbal, Yaw, and Ankomah (2020) found ESE affects El. Shahab, Chengang, Arbizu, and Haider (2018) study also showed that selfefficacy affects El. An evaluation of the relationship between ESE and El was carried out by Chu, Sun, Yang, Zheng, and Li (2020), and their study found that ESE positively affects EI.

According to this paper, an individual's decision to act is influenced by their self-belief in their ability to achieve an expected result, so the higher the self-efficacy of young adults, the more likely they are to engage in a venture. 
The study by Wang and Huang (2019) supported this argument with their findings revealing that ESE has a significant and positive effect on El. Garaika and Margahana's (2019) study also showed that ESE has an adverse effect on entrepreneurship intentions. Hence, we hypothesize that:

$H_{1}$ : Entrepreneurial self-efficacy has a significant effect on Entrepreneurial Intention among graduates in Nigeria.

\section{Mediating role of the need for independence on entrepreneurial self- efficacy and EI}

The need for independence entails bearing the burden of depending on one's decision, which differs from relying on and following the decision of others. It means being in charge of one's life rather than leaving it in the hands of others (Shava \& Chinyamurindi, 2019). Moreover, entrepreneurship requires independence, as an entrepreneur must go after opportunities that are not usually visible to others and he or she bears the burden of the consequence of his/her decision regardless of whether it is favorable or not. Independence in relation to entrepreneurship means a disposition to be able to make a judgment without influence from peripheral elements. It also depicts a yearning for independence, with no superior control and the ability to design one's job (Giacomin, Janssen, Guyot, \& Lohest, 2011).

Independence depicts a person's craving for autonomy, management, and plasticity. To Peng and Kang (2012), it is a desire to chase the entrepreneurial professional lane. The idea of independence to an entrepreneur may be a leeway to his or her inbuilt character and may express his or her fundamental thought process. It is an everyday resolve to lead his or her life and establishment. It is noted that individuals who are self-employed are more satisfied because of the freedom they enjoy managing their business affairs (Lange, 2012). Pursing independence entails individuals wanting to separate themselves from apparent restrictions within the environment they find themselves in (Eijdenberg \& Masurel, 2013).

The need for independence is a psychological step towards an individual's desire to own and manage a business of their own. It is expected to affect a person's intent to engage in a venture because independence denotes being your own boss, managing and making decisions without external interference (Croson \& Minniti, 2012). Dalborg and Wincent (2015) asserted that independence is the major benefit of entrepreneurship. The need for independence is a major psychological, motivational driver towards an entrepreneurial decision of an individual (Nsahlai, Zogli, Lawa, \& Dlamini, 2020). There are greater chances that an individual who seeks the 
need to be independent will start up a venture of their own, because, most often, independence is what forms a major part and reason for an individual who decided to become an entrepreneur.

Moreover, it was found that independence and other elements like character, principles, and self-sufficiency increase job satisfaction. Hence, people who are more inclined towards non-financial facets of job relationships are more prepared to let go of a salary in order to enhance the non-financial facet of their work (Croson \& Minniti, 2012). Tyszka, Cieślik, Domurat, and Macko (2011) reiterated that entrepreneurs are probably more driven by the need to be independent than any other motivation, which also helps in shaping their intention and actions to start a business of their own. The study by Omar et al. (2019) found that the need for independence affects students' intention to start a venture. Barba-Sánchez and Atienza-Sahuquillo's (2018) study confirms that the need for independence accounts for the intent to start a new venture. Malebana (2021) also found that the need for independence affects El. Hence, we hypothesize that:

\section{$H_{2}:$ The needfor independence has a significant effect on the Entrepreneurial} Intention of graduates in Nigeria.

The importance of self-efficacy on entrepreneurship cannot be overemphasised, as it has been demonstrated to have a positive effect on the performance of individuals (Haddad \& Taleb, 2016). Haddad and Taleb (2016) further pointed out that self-efficacy can be seen in four facets, namely experience, vicarious experience, verbal persuasion and emotional cues, and all these facets except the last one had a favourable effect on performance. This implies that self-efficacy may not be sufficient towards driving intention, as it is dependent on a reason. For El to evolve, there is a need for the drive to be self-employed, as well as an awareness of apparent entrepreneurial prospects and the availability of resources that will aid the process of becoming self-employed.

The need for independence is a psychological force that stimulates selfbelief and drives individual resolution towards a course of action. It has mainly been characterized as entrepreneurial motivation in the literature (Shava \& Chinyamurindi, 2019). Kautonen et al. (2013) asserted that although the theory of planned behavior identified individual and societal elements that can lead to El, the theory did not take into account the probability of El being foiled as a result of obstacles that are avoidable and non-avoidable. This is significant because, regardless of one's self-belief, there are obstacles that can deter them from embarking on a venture. However, when there is a need for independence, it can instill a greater depth of perseverance that allows 
the individual to be persistent and overcome any obstacle, which is a gap that this study seeks to close, as we propose that the need for independence is a factor in the process between ESE and El.

However, ESE is not the only factor responsible for intention, but its favorable effect on intention has been largely captured in the literature (Shinnar, Hsu, \& Powell, 2014; Bae, Qian, Miao, \& Fiet, 2014). The essential role self-efficacy plays on El is buttressed as it helps towards having a regulatory effect on mere creative disposition and an actual willingness to start and engage in a venture. Individuals may decide to be an entrepreneur so as to be independent. This decision is the reason that accounts for the process through which self-efficacy is developed towards ensuring that they become entrepreneurs, as self-efficacy does not just develop immediately. When an individual develops a need for independence, which is often referred to as the need for autonomy (Shava \& Chinyamurindi, 2019), it is most likely that the individual will rely on their experience in making the decision to start a venture.

The intention of starting a business is not easily developed given the fact that most entrepreneurs are aware of the obstacles that could deter them from engaging in a venture. However, when an individual desires to be their own boss, it acts as a propeller that steers the individual to develop not just interest but also the ability to identify opportunities, engage in them, and drive self-sufficiency. Further, specific peculiarities serve as the basis for the establishment of an ingenious commercial venture, as what is considered a prospect by a prospective entrepreneur may be considered a requisite by another (Giacomin, Janssen, Pruett, Shinnar, Llopis, \& Toney, 2010). Furthermore, the decision to start a business is usually thoroughly considered; thus, individuals with a greater depth of apparent prestige, practicability, and a favorable disposition toward entrepreneurship, combined with a desire for independence as well as apparent attitude regulation, are more likely to develop El (Solesvik, Westhead, Kolvereid, \& Matlay, 2012).

Also, an entrepreneur's extent of perseverance even in the midst of obstacles depends on his or her desire for independence (Martinez \& Bryant, 2014). Differences in the desire for independence could depend on openness to experience, which allows an entrepreneur to see obstacles as a means of acquiring knowledge and expanding their knowledge base. Hence, having an appropriate entrepreneurial mindset that desires independence is the means by which ESE can influence El. Maes, Leroy, and Sels (2014) opined that individual behavior as well as observed conduct act incidentally with societal beliefs in developing an individual's intention in respect of starting a business. The need for independence is drawn from inward regulation, and Maes et al. (2014) observed that inward regulation is connected to an 
individual's capacities, which, as an attitudinal regulation, has a favorable impact on intention.

Paez and García (2011) and Mora (2011) opined that the desire for independence is an element that has a considerable influence on promoting El. Hence, Lortie and Castogiovanni (2015) opined that intention comes first before any action is taken. Intentions are comprehended by apprehending elements of incentive that affect attitude and by the extent of effort the person with the intention to implement possesses, so as to achieve his/her goal. Our paper argues that the need for independence is the internal mechanism that accounts for the changes in an individual's ESE, since we believe that ESE is dynamic and not static (Bledow, 2013; Newman et al., 2019). Hence, we hypothesize that:

$H_{3}$ : The need for independence mediates the relationship between Entrepreneurial Self-efficacy and Entrepreneurial Intention.

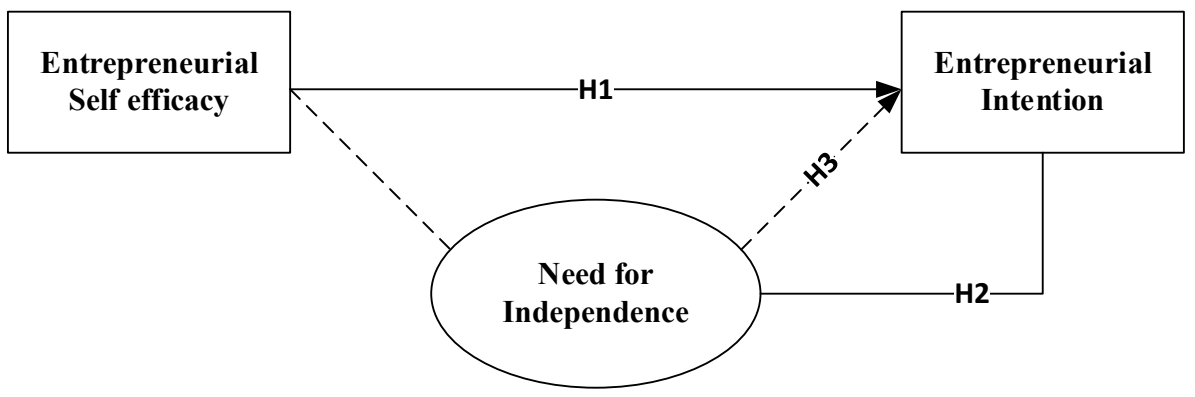

Figure 1. Conceptual model showing the link between ESE, the need for independence and $\mathrm{EI}$

\section{METHODOLOGY}

Survey design was used, and this technique's choice was premised on the need to collect data from a large population. The study sample was 350 graduates participating in the National Youth Service Corp in twelve states in Nigeria. The study selected two states in each of the six geopolitical zones in the country. The selection of the respondents for the study was based on the willingness of the graduates to participate in the survey. This corps of graduates was chosen because they are young graduates who have recently graduated from university and have participated in entrepreneurship education programs at the university, which means they have a higher likelihood of intending to start a business. Also, this was done to close gaps in studies that mainly focused 
on students, most especially on studies on El, with limited studies accounting for new graduates, who would have better responses on El. The study made use of a technique known as purposive sampling. The internal consistency method was used for reliability, while construct and content were used for the validity of the instrument. The partial least square structural equation model (PLS-SEM) was used for the analysis of the study data and this was done with the aid of SmartPLSv3.

\section{Measures}

\section{Entrepreneurial self-efficacy}

The scale for ESE was adapted from the study by Zhao, Seibert, and Hills (2005). The scale consists of four items. However, we added two new items to make the total items in the scale to be six and these were used to measure the construct. The scale was created using a five-point Likert format, with values ranging from 1 (no confidence) to 5 (complete confidence). Content validity was carried out on the items on the scale and a V-rating of 0.811 was obtained, indicating the items were rated highly. Two examples from the scales are "I have the capacity to raise resources for my business," and "I can create a working environment that supports new initiatives and ways of doing things."

\section{Need for independence}

The study adapted the unidimensional scale from the study of Singelis (1994), measuring independent self-construal. However, the scale was slightly modified to suit the current study. The instrument was created in the form of a 7-point Likert scale. The scale consists of 15 items, and samples from the scale are "I prefer to be direct and forthright when dealing with things that affect me," "I value having my peace of mind and being in good health above other things" and "I am able to act the same way in every action that affects me." The scale was subjected to content validity using two experts in psychology and entrepreneurship and a V-rating of 0.812 was obtained for the scale.

\section{Entrepreneurial intention}

The study adapted the instrument of Shahab, Chengang, Arbizu, and Haider (2018) for measuring El. The instrument is made up of six Likert scale-style items. The choice of the instrument is because of its reliability and validity 
of the instrument. The instrument was subjected to content validity by two experts, one entrepreneurship and measurement and evaluation. A V-ratio of 0.792 was obtained, indicating a high rating of the items on the scale. Samples from the scale are "I am ready to start a business of my own," "I desire to establish a business that will solve problems" and "I do not have the willingness to start a business."

Since the instrument was adapted from previous studies and the need to confirm the independence of the constructs, we conducted a confirmatory and exploratory factor analysis respectively from a sample of 120 finalyear students at Federal University Wukari and Enugu State University. The exploratory factor analysis provided support that the constructs are separate and independent. The two-model approach was adopted in the confirmatory factor analysis using SPSS AMOS, as the one-factor model for the variables confirmed a fit of the models for all the variables. An overall fit was then further assessed and the result produced a much better fit. The indices obtained were in line with a scholarly position (MacCallum \& Hong, 1997; Hooper et al., 2008). The fits were satisfactory as (CMIN/DF) $=312, p<0.01$, $\mathrm{GIF}=0.911, \mathrm{SRMR}=0.008, \mathrm{CFI}=0.920$ and $\mathrm{RMSEA}=0.644$.

\section{RESULT AND DISCUSSIONS}

We ensured that the instruments were separated into sections. This was done to avoid bias in responses, since the same respondents were providing responses on the constructed scales. Also, we conducted a factor analysis and found none of the factors accounted for more than $50 \%$, as the need for independence had the highest figure and accounted for $33 \%$ of the variance. This implies the result from the study would not be affected by common method variance (Podsakoff, MacKenzie \& Podsakoff, 2012). We also ran an independent sample t-test on the retrieved items to see if there was a difference between the instruments that were rejected and those that were used in the study. The result showed that there was no significant difference $(F=213, p<0.01)$. Further, two hundred and thirty-five questionnaires, which constitute $67 \%$ of the total distributed questionnaires, were found usable out of the three hundred and fifty that were distributed across the six states selected from the six geopolitical zones in the country.

The demographic characteristics of the respondents from Table 1 show that males are 126 (54\%) while females are 109 (46\%).

Respondents that have started a business before were $7(3 \%)$, those that have never were 182 (77\%) while those that have managed for others were $46(20 \%)$. The age distribution shows that respondents between the ages of 
18-21 years were 129 (55\%), those within the age of $22-25$ years were 91 (39\%), those within the age of $26-30$ years were $15(6 \%)$.

Table 1. Characteristics of respondents

\begin{tabular}{ll}
\hline Demographic features & Frequency \\
\hline Gender & $126(54 \%)$ \\
Male & $109(46 \%)$ \\
Female & $235(100 \%)$ \\
Total & \\
\hline Previous business experience & $182(77 \%)$ \\
Never started a business & $7(3 \%)$ \\
Had started a business before & $46(20 \%)$ \\
Managed a business for others & $235(100 \%)$ \\
Total & \\
\hline Age & $129(55 \%)$ \\
$18-21$ years & $91(39 \%)$ \\
$22-25$ years & $15(6 \%)$ \\
$26-30$ years & $235(100 \%)$ \\
Total & \\
\hline
\end{tabular}

Since the current study was interested in only young adults that are graduates, the age bracket of the respondents was limited to persons within the ages of 18-30 years. Also, the National Youth Service Corp from which the participants were selected from does not allow persons above 30 years of age to partake in the scheme.

\section{Measurement model}

The disjoint two-stage approach was used and the result from the analysis produced a measurement of the model first. The result, as presented in Table 2 below, shows the factor loading of the constructs. Given the values were above 0.70 , all items on the scale were sufficiently loaded, and as a result, none of the items was removed (Hair, Howard, \& Nitzl, 2020). The rho_A and Cronbach alpha was an internal consistency measure of reliability and the result shows that scale was reliable given that the coefficient obtained from the analysis was within the threshold of above 0.70 (Hair, Risher, Sarstedt, \& Ringle, 2019). Convergent validity was also confirmed with the result. It showed that the average variance extracted (AVE) was above 0.50, which implies a high level of convergent validity (Hair et al., 2020). 
104 / Entrepreneurial self-efficacy and entrepreneurial intention: The mediating role of the need for independence

Table 2. Result on Entrepreneurial Self-efficacy, Need for Independence, and Intention

\begin{tabular}{|c|c|c|c|c|c|}
\hline & Loadings & rho_A & $\begin{array}{c}\text { Cronbach } \\
(\infty)\end{array}$ & $\begin{array}{c}\text { Average } \\
\text { Variance } \\
\text { Extracted } \\
\text { (AVE) }\end{array}$ & $\begin{array}{l}\text { Composite } \\
\text { Reliability }\end{array}$ \\
\hline Entrepreneurial Self-efficacy & & 0.849 & 0.762 & 0.557 & 0.834 \\
\hline ESE 1 & 0.784 & & & & \\
\hline ESE 2 & 0.711 & & & & \\
\hline ESE 3 & 0.755 & & & & \\
\hline ESE 4 & 0.774 & & & & \\
\hline ESE 5 & 0.750 & & & & \\
\hline ESE 6 & 0.764 & & & & \\
\hline Need for Independence & & 0.899 & 0.892 & 0.601 & 0.908 \\
\hline NFI 1 & 0.798 & & & & \\
\hline NFI 2 & 0.701 & & & & \\
\hline NFI 3 & 0.721 & & & & \\
\hline NFI 4 & 0.756 & & & & \\
\hline NFI 5 & 0.717 & & & & \\
\hline NFI 6 & 0.774 & & & & \\
\hline NFI 7 & 0.780 & & & & \\
\hline NFI 8 & 0.775 & & & & \\
\hline NFI 9 & 0.710 & & & & \\
\hline NFI 10 & 0.785 & & & & \\
\hline NFI 11 & 0.735 & & & & \\
\hline NFI 12 & 0.742 & & & & \\
\hline NFI 13 & 0.728 & & & & \\
\hline NFI 14 & 0.741 & & & & \\
\hline NFI 15 & 0.769 & & & & \\
\hline Entrepreneurial Intention & & 0.849 & 0.841 & 0.564 & 0.884 \\
\hline ENI 1 & 0.846 & & & & \\
\hline ENI 2 & 0.776 & & & & \\
\hline ENI 3 & 0.760 & & & & \\
\hline ENI 4 & 0.823 & & & & \\
\hline ENI 5 & 0.755 & & & & \\
\hline ENI 6 & 0.717 & & & & \\
\hline
\end{tabular}


Henseler, Ringle and Sarstedt (2015) opined that the heterotrait-monotrait (HTMT) was a more robust discriminant validity criterion when compared to the Fornell and Larcker criterion and the cross-loadings when using a variancebased SEM. Table 3 below shows the heterotrait-monotrait (HTMT) values for the study. The result indicates that the discriminant validity criterion was satisfied, given that none of the values was above 0.85 (Henseler et al., 2015; Hair et al., 2020). This implies that discriminant validity was confirmed for this study. We then followed the recommendation of Franke and Sarstedt (2019) and conducted a $95 \%$ bootstrap-based confidence interval. This was done to confirm that the threshold is within the intervals. The result also confirms that none of the HTMT values was statistically different from 1 , which is a further confirmation of the discriminant validity of the study.

Table 3. Heterotrait-Monotrait Ratio (HTMT)

\begin{tabular}{llll}
\hline & $\begin{array}{l}\text { Entrepreneurial } \\
\text { Self-efficacy }\end{array}$ & $\begin{array}{l}\text { Entrepreneurial } \\
\text { Intention }\end{array}$ & $\begin{array}{l}\text { Need for } \\
\text { Independence }\end{array}$ \\
\hline Entrepreneurial Self-efficacy & & & \\
\hline Entrepreneurial Intention & 0.137 & & \\
\hline Need for Independence & 0.149 & 0.759 \\
\hline
\end{tabular}

\section{Structural model}

The structural path model for the study was further assessed. The result from the loading shows the presence of a weak relationship between ESE and El. However, when the relationship was mediated by the need for independence, the relationship was stronger. The result shows a moderate relationship between ESE and the need for independence. The significance of the paths was conducted using the bootstrapping approach, which was conducted with 5,000 samples and using the no sign changes option, bias-corrected and accelerated ( $\mathrm{BCa}$ ) bootstrap confidence interval, and two-tailed testing at 0.05. A summary of the results is presented in Table 4 below. The result shows that the path between ESE and El was not significant, as the p-value was above 0.05 . The need for independence was found to have a significant effect on El; as a result, it shows that the p-value was less than 0.05 and, finally, the result shows that the path indicates the mediating effect of the need for independence on ESE and El was found to be positive and significant.

The significance of the path loadings is shown in Figure 2 below. The diagram confirms the summarised table result that shows that ESE does not significantly affect El, given the t-value is less than 1.96. The path between the need for independence and intention was confirmed. 
Table 4. Result and Decision on HRM Practices and performance

\begin{tabular}{llll}
\hline & T-Statistics & P-Value & Outcome \\
\hline Self-efficacy -> Intention & 0.181 & 0.857 & ${\text { Reject } \mathbf{H}_{1}}$ \\
\hline Independence $->$ Intention & 12.300 & 0.000 & ${\text { Accept } \mathbf{H}_{2}}$ \\
\hline Self-efficacy $->$ Independence $->$ Intention & 9.997 & 0.000 & ${\text { Accept } \mathbf{H}_{3}}$ \\
\hline & $\mathbf{R}^{\text {-square }}$ & $\mathbf{Q}^{2}$ & \\
Entrepreneurial intention $=$ & $\mathbf{5 5 . 8 \%}$ & $\mathbf{0 . 3 3 6}$ & \\
Need for independence $=$ & $\mathbf{6 3 . 4 \%}$ & $\mathbf{0 . 5 2 9}$ &
\end{tabular}

Note: N.B: $\mathbf{Q}^{2}=$ predictive validity.

This implies that $\mathrm{H}_{1}$ is not supported by the findings of this study, while $\mathrm{H}_{2}$ and $\mathrm{H}_{3}$ are supported based on the result of the analysis. The model insample fit was determined using R-square, and the result shows that the model explains $63.4 \%$ and $55.8 \%$ of variance in the need for independence and $\mathrm{El}$, respectively. The remaining $36.6 \%$ and $44.2 \%$ could be attributable to other factor(s) not captured in the model.

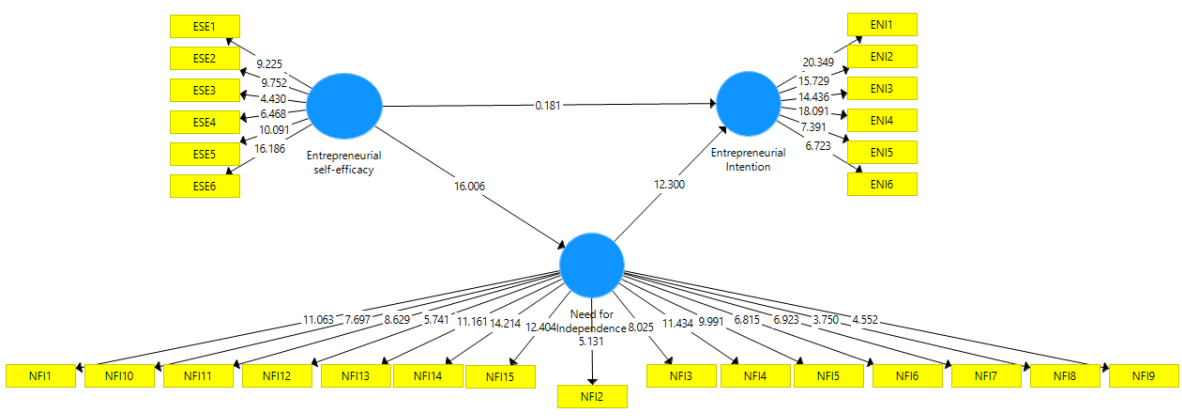

Figure 2. Significance of the link between ESE, the need for independence, and EI Source: Researchers' SmartPLS output.

We also used PLSpredict to assess the predictive power of the study model. Shmueli et al. (2019) stated that $Q^{2}$-values above zero indicate good predictive relevance. Since the values from Table 4 were above zero, it thus implies that the model has a good predictive relevance. Model fit was assessed using the standardized root mean square (SRMR), and the result shows an index of 0.042 . Hair et al. (2017) recommended that for model fit using SRMR values, the values should be below 0.08. Hence, given the SRMR value for this study is 0.042 , it thus implies that the model is fit.

The paper examined the mediating effect of the need for independence between ESE and El. The two hundred and thirty-five usable instruments retrieved from respondents were used for the further analysis of the study. 
The measurement model shows the criterion was satisfied, which justified the structural model assessment. The structural assessment produced quite startling results that provide a new insight for scholars.

The outcome of the analysis confirmed that ESE does not have a significant effect on El. The result showed the t-value to be less than 1.96 and a $p$-value greater than 0.05 . This result is quite surprising given the relevance of selfefficacy in an individual's decision-making process. This result differs from the study of Akhtar et al. (2020), Shahab et al. (2018), Chu et al. (2020), and Wang and Huang (2019). The difference in findings could be because of differences in geographical scope where the studies were undertaken. The differences could also be because self-efficacy is not equal in all individuals, most especially when the current study used fresh graduates, as experience and knowledge have been found to affect self-efficacy, which the majority of the young graduates may not have.

Further, it was found that the need for independence affects El. This result is consistent with the findings of Omar et al. (2019), and BarbaSánchez and Atienza-Sahuquillo (2018) that found that the need for independence affects El. Also, this result supports Hessels, Rietveld, and van der Zwan (2017) position that the tendency to be an entrepreneur is greater owing to the need for independence and job control. This implies that the need for independence is vital for young graduates, as it is a necessary trigger to stimulate El. The link between the need for ESE and the need for independence was also found to be significant, though not hypothesized in this study. This implies that when entrepreneurs develop a need for independence, it would account for their ability to develop an inner state of self-belief that drives self-confidence.

Finally, the mediating role of the need for independence on ESE and EI was found to be positive and significant. The result is consistent with the views of Bledow (2013) and Newman et al. (2019) on the presence of an internal mechanism that accounts for changes in ESE. This implies that for an individual's self-efficacy to result in a string of intentions to start a business, it then means that the individual must first develop an interest in being independent. Young adults have a strong quest for independence and, when attained, it develops confidence and self-belief, which is useful in encouraging them towards starting a venture of their choice Chu et al. (2020). The result confirms that the need for independence fully mediates the link between ESE and El. This implies that when an entrepreneur can channel its self-efficacy through the need for independence, both of which are psychological actions, it will produce greater inner confidence towards starting a venture of interest, as self-belief is obviously not enough. 


\section{CONCLUSION}

In the hope of addressing the gap in studies that accounts for the reason for the low El, despite increasing government efforts steering young graduates towards venture creation and accounting for the factors that could cognitively support their interest in venture creation, this study broadened our understanding on how the need for independence indirectly accounts for the process between a graduate's self-efficacy and entrepreneurial intention. To this end, we conclude that graduates' self-belief cannot drive the intention towards starting a venture. Therefore, it may be right to assume that graduates' inability to drive venture creation could be because of external factor(s) such as the evident inability to access capital or support funds to establish a business of their own and the hostile business climate in Nigeria that is relatively harsh to new entrants.

Further, the study concludes that a young graduate's decision to create a venture could be best achieved through a cognitive process that demands an individual's need for independence. Therefore, it may be judicious to assume that the evident poor job security, inability to access capital, hostile business environment and weak labor practices in the country weakens their self-belief, thus demanding a cognitive process that deliberately highlights the need for independence, as a precursor towards entrepreneurial intention.

This paper presents both theoretical and practical implications for research on unraveling the link between ESE, the need for independence, and El among young graduates in Nigeria. We drew upon the behavioral reasoning theory to enhance our understanding of how ESE transmits its effect on young graduates' intentions to be entrepreneurs. Though our study found ESE not to be the reason that could account for young graduates' intentions to be entrepreneurs, it did, however, indicate that when their individual ESE is channeled through the desire to be independent, there is a greater chance that young graduates in the country would desire to be entrepreneurs.

This paper provides new insight into the behavioral reasoning theory through its application in explaining the cognitive role in decision-making, using samples from a developing economy. The study validates the behavioral reasoning theory and supports its application in entrepreneurship literature given the paucity of studies that have adopted the theory, despite its relevance in emphasizing unraveling fundamental underlining reasons that account for an entrepreneur's action.

Further, the study advances the need for increased personality development modules for young adults in the country. There is a need for them to explore their self-belief in their abilities and skills through a deliberate desire to be independent, as it will be useful towards ensuring that they focus 
less on the threats that could deter them from being entrepreneurs. This is also important in view of the challenges that are faced in starting a business in the country. This paper confirms that their self-belief may not be enough, as there is a need to educate them on the benefits of being independent. This is very important given the time we are in as a nation, where there are limited white-collar jobs to go around and the spiraling rise in unemployment and crime in the country.

In addition, this paper immensely contributes to the entrepreneurship literature by providing an empirical study that advances a new perspective on ESE by providing scholarly evidence of the factors that cause within-person variance or fluctuations in ESE, which is a gap not previously covered in the literature. The paper highlights the need for more insight into personality traits, uncovering newer dimensions not accounted for in the literature.

Despite the far-reaching relevance of this study to the entrepreneurial literature, there are some limitations that arise from this study. First, the study was limited to a survey design, and, as such, future studies could adopt a longitudinal design towards accounting for the link between ESE and El. Next, the study was limited to young graduates who had just completed their university education. Therefore, future studies could undertake a comparison between fresh graduates and students who are still in school. Also, as the study was limited to a quantitative perspective, future studies could adopt a qualitative paradigm to the study and, where possible, a mixed-method approach.

\section{Acknowledgments}

We wish to acknowledge the management of the University of Nigeria for their support in undertaking the research, the journal Editor in Chief, and the independent Reviewers, whose comments helped improve the manuscript's final draft.

\section{References}

Akhtar, S., Hongyuan, T., Iqbal, S., Yaw, F., \& Ankomah, F. (2020). Impact of need for achievement on entrepreneurial intentions: Mediating role of self-efficacy. Journal of Asian Business Strategy, 10(1), 114-121. https:// doi.org/10.18488/journal.1006.2020.101.114.121

Arshad, M., Farooq, O., Sultana, N., \& Farooq, M. (2016). Determinants of individuals' entrepreneurial intentions: A gender-comparative study. Career Development International, 21(4), 318-339. http://dx.doi. org/10.1108/CDI-10-2015-0135 
Ayodele, K. (2013). Demographics, entrepreneurial self-efficacy and locus of control as determinants of adolescents' entrepreneurial intention in Ogun State, Nigeria. European Journal of Business and Social Sciences, 1(12), 59-67. https://publication.babcock.edu.ng/asset/docs/publications/ EDFO/9454/3281.pdf

Bae, J., Qian, S., Miao, C., \& Fiet, J. (2014). The relationship between entrepreneurship education and entrepreneurial intentions: A metaanalytic review. Entrepreneurship Theory and Practice, 38(2), 217-254. http://dx.doi.org/10.1111/etap.12095

Barba-Sánchez, V., \& Atienza-Sahuquillo, C. (2018). Entrepreneurial intention among engineering students: The role of entrepreneurship education. European Research on Management and Business Economics, 24(1), 5361. http://dx.doi.org/10.1016/j.iedeen.2017.04.001

Bledow, R. (2013). Demand-perception and self-motivation as opponent processes: A response to Bandura and Vancouver. Journal of Management, 39(1), 14-26. http://dx.doi.org/10.1177/0149206312466149

Calza, F., Cannavale, C., \& Zohoorian Nadali, I. (2020). How do cultural values influence entrepreneurial behavior of nations? A behavioral reasoning approach. International Business Review, 29(5), 101725-101730. https:// doi.org/10.1016/j.ibusrev.2020.101725

Chu, C., Sun, B., Yang H., Zheng, M., \& Li, B. (2020). Emotional competence, entrepreneurial self-efficacy, and entrepreneurial intention: A 'study based on China college students' social entrepreneurship project. Frontiers in Psychology, 11, 2883. http://dx.doi.org/10.3389/ fpsyg.2020.547627

Croson, D. C., \& Minniti, M. (2012). Slipping the surly bonds: The value of autonomy in self-employment. Journal of Economic Psychology, 33(2), 355-365. http://dx.doi.org/10.1016/j.joep.2011.05.001

Dalborg, C., \& Wincent, J. (2014). The idea is not enough: The role of selfefficacy in mediating the relationship between pull entrepreneurship and founder passion - a research note. International Small Business Journal, 33(8), 974-984. http://dx.doi.org/10.1177/0266242614543336

Densberger, K. (2014). The self-efficacy and risk-propensity of entrepreneurs. Journal of Enterprising Culture, 22(4), 437-462. https://doi.org/10.1142/ S0218495814 500186

Devonish, D., Alleyne, P., Charles-Soverall, W., Marshall, A., \& Pounder, P. (2010). Explaining entrepreneurial intentions in the Caribean. International Journal of Entrepreneurial Behaviour and Research, 16(2), 149-171. https://doi.org/10.1108/13552551011027020

Douglas, E., \& Fitzsimmons, J. (2013). Intrapreneurial intentions versus entrepreneurial intentions: Distinct constructs with different antecedents. Small Business Economics, 41(1), 115-132. https://doi. org/10.1007/s11187-012-9419-y

Eijdenberg, E.L., \& Masurel, E. (2013). Entrepreneurial motivation in a least developed country: Push factors and pull factors among MSEs IN Uganda. 
Journal of Enterprising Culture, 21(1), 19 -43. https://doi.org/10.1142/ s0218495813500027

Franke, G. R., \& Sarstedt, M. (2019). Heuristics versus statistics in discriminant validity testing: A comparison of four procedures. Internet Research, 29(3), 430-447. https://doi.org/10.1108/IntR-12-2017-0515

Garaika, G., \& Margahana, H. (2019). Self efficacy, self personality and self confidence on entrepreneurial intention: Study on young enterprises. Journal of Entrepreneurship Education, 22(1), 1-12. https://www.abacademies.org/articles/self-efficacy-self-personalityand-self-confidence-on-entrepreneurial-intention-study-on-youngenterprises-7647.html

Giacomin, O., Janssen, F., Pruett, M., Shinnar, R., Llopis, F., \& Toney, B. (2010). Entrepreneurial intentions, motivations, and barriers: Differences among American, Asian and European Students. International Entrepreneurship Management Journal, 7(2), 219-238. https://doi.org/10.1007/s11365010-0155-y

Giacomin, O., Janssen, F., Guyot, J., \& Lohest, O. (2011). Opportunity and/ or necessity entrepreneurship? The impact of the socio-economic characteristics of entrepreneurs. MPRA Paper 29506, University Library of Munich, Germany. Retrieved from https://mpra.ub.uni-muenchen. de/29506/2/MPRA_paper_29506.pdf

Gigerenzer, G., \& Goldstein, D. G. (1996). Reasoning the fast and frugal way: Models of bounded rationality. Psychological Review, 103(4), 650669. https://doi.org/10.1037/0033-295X.103.4.650

Haddad, S., \& Taleb, R. (2016). The impact of self-efficacy on performance: An empirical study on business faculty members in Jordanian universities. Computers in Human Behavior, 55(1), 877-887. https://doi.org/10.1016/j. chb.2015.10.032

Hair, J. F., Binz Astrachan, C., Moisescu, O. I., Radomir, L., Sarstedt, M., Vaithilingam, S., \& Ringle, C. M. (2020). Executing and interpreting applications of PLS-SEM: Updates for family business researchers. Journal of Family Business Strategy, 100392, https://doi.org/10.1016/j. jfbs.2020.100392

Hair, J. F., Black, B., Babin, B., \& Anderson, R. E. (2014). Multivariate data analysis $\left(7^{\text {th }}\right.$ ed.). Upper Saddle River, NJ: Pearson Prentice Hall.

Hair, J. F., Howard, M. C., \& Nitzl, C. (2020). Assessing measurement model quality in PLS-SEM using confirmatory composite analysis. Journal of Business Research, 109, 101-110. https://doi.org/10.1016/j. jbusres.2019.11.069

Hair, J. F., Risher, J. J., Sarstedt, M., \& Ringle, C. M. (2019). When to use and how to report the results of PLS-SEM. European Business Review, 31(1), 2-24. https://doi.org/10.1108/EBR-11-2018-0203

Hair, J.F., Hult, G.T.M., Ringle, C.M., \& Sarstedt, M. (2017). A Primer on Partial Least Squares Structural Equation Modeling (PLS-SEM), 2nd ed.. Thousand Oaks, CA.: Sage Publications. 
Henseler, J., Ringle, C.M., \& Sarstedt, M. (2015). A new criterion for assessing discriminant validity in variance-based structural equation modelling. Journal of the Academy of Marketing Science, 43(1), 115-135. http://doi. org/10.1007/s11747-014-0403-8

Hessels, J., Rietveld, C. A., \& van der Zwan, P. (2017). Self-employment and work-related stress: The mediating role of job control and job demand. Journal of Business Venturing, 32(2), 178-196. https://doi.org/10.1016/j. jbusvent.2016.10.007

Hooper, D., Coughlan, J., \& Mullen, M. R. (2008). Structural equation modelling: Guidelines for determining model fit. Electronic Journal of Business Research Methods, 6(1), 53-60. https://academic-publishing. org/index.php/ejbrm/article/view/1224/1187

Horvath, Z. E. (2016). Assessing calling as a predictor of entrepreneurial interest. Society and Economy, 38(4), 513-535. https://doi. org/10.1556/204.2016.38.4.5

Hsu, D. K., Wiklund, J., \& Cotton, R. D. (2017). Success, failure, and entrepreneurial reentry: An experimental assessment of the veracity of self-efficacy and prospect theory. Entrepreneurship Theory and Practice, 41(1), 19-47. https://doi.org/10.1111/etap.12166

Kautonen, T., Gelderen, M. V., \& Tornikoski, T. (2013). Predicting entrepreneurial behaviour: A test of the theory of planned behaviour. Applied Economics, 45(6), 697-707. https://doi.org/10.1080/00036846. 2011.610750

Kautonen, T., Gelderen, M., \& Fink, M. (2015). Robustness of the theory of planned behavior in predicting entrepreneurial intentions and actions. Entrepreneurship Theory and Practice, 39(3), 655-674. https://doi. org/10.1111\%2Fetap.12056

Kautonen, T., Hatak, I., Kibler, E., \& Wainwright, T. (2015). Emergence of entrepreneurial behaviour: The role of age-based. Journal of Economic Psychology, 50, 41-51. https://doi.org/10.1016/j.joep.2015.07.004

Khedhaouria, A., Gurau, C., \& Torrès, O. (2014). Creativity, self-efficacy, and small-firm performance: The mediating role of entrepreneurial orientation. Small Business Economics, 44(3), 485-504. https://doi. org/10.1007/s11187-014-9608-y

Lange, T. (2012). Job satisfaction and self-employment: Autonomy or personality? Small Business Economics, 38(2), 165-177. https://doi. org/10.1007/s11187-009-9249-8

Liñán, F., \& Fayolle, A. (2015). A systematic literature review on entrepreneurial intentions: Citation, thematic analyses, and research agenda. International Entrepreneurship and Management Journal, 11(4), 907933. https://doi.org/10.1007/s11365-015-0356-5

Linan, F., Nabi, G., \& Krueger, N. (2013). British and Spanish entrepreneurship intentions: A comparative study. Revista de Economia Mundial, 33, 73103. http://www.redalyc.org/articulo.oa?id $=86626373004$ 
Linan, F., Rodriguez-Cohard, C., \& Rueda-Cantuche, M. (2011). Factors affecting entrepreneurial intension levels: A role for education. International Entrepreneurship Management Journal, 7(2), 195-218. https://doi.org/10.1007/s11365-010-0154-z

Lortie, J., \& Castogiovanni, G. (2015). The theory of planned behavior in entrepreneurship research: What we know and future directions. International Entrepreneurship and Management Journal, 11(4), 935957. https://doi.org/10.1007/s11365-015-0358-3

Lorz, M. (2011). The Impact of Entrepreneurship Education on Entrepreneurial Intention (Doctoral dissertation). Gallen: University of St. Gallen.

MacCallum, R. C., \& Hong, S. (1997). Power analysis in covariance structure modeling using GFI and AGFI. Multivariate Behavioral Research, 32(2), 193-210. https://doi.org/10.1207/s15327906mbr3202_5

Maes, J., Leroy, H., \& Sels, L. (2014). Gender differences in entrepreneurial intentions: A TPB multi-group analysis at factor and indicator level. European Management Journal, 32(5), 784-794. https://doi. org/10.1016/j.emj.2014.01.001

Malebana, M. J. (2021). The effect of entrepreneurial motivation on entrepreneurial intention of South African rural youth. Academy of Entrepreneurship Journal, 27(3), 1-14. https://www.abacademies.org/ articles/the-effect-of-entrepreneurial-motivation-on-entrepreneurialintention-of-south-african-rural-youth-10395.html

Martinez, C., \& Bryant, P.T. (2017). What keeps entrepreneurs entrepreneurial? A regulatory focus theory of entrepreneurial persistence. Academy of Management Proceedings, 2014(1). http://dx.doi.org/10.5465/ ambpp.2014.14802abstract

Meyer, D. (2011). The reinvention of academic entrepreneurship. Journal of Small Business Management, 49(1), 1-8. https://doi.org/10.1111/j.1540627X.2010.00311.X

Miao, C., Qian, S., \& Ma, D. (2016). The relationship between entrepreneurial self-efficacy and firm performance: A meta-analysis of main and moderator effects. Journal of Small Business Management, 55(1), 87107. https://doi.org/10.1111/jsbm.12240

Miralles, F., Giones, F., \& Gozun, B. (2017). Does direct experience matter? Examining the consequences of current entrepreneurial behavior on entrepreneurial intention. International Entrepreneurship and Management Journal, 13(3), 881-903. https://doi.org/10. 1007/s11365016-0430-7

Moriano, A., Gorgievski, M., Laguna, M., Stephan, U., \& Zarafshani, K. (2012). A cross-cultural approach to understanding entrepreneurial intention. Journal of Career Development, 39(2), 162-185. https://doi. org $/ 10.1177 \% 2 F 0894845310384481$

Mumtaz, K., Munirah, S., \& Halimahton, K. (2012). The relationship between educational support and entrepreneurial intentions in Malaysian higher 
learning institution. Procedia - Social and Behavioral Sciences, 69, (24), 2164-2173. https://doi.org/10.1016/j.sbspro.2012.12.182

Neneh, B. N. (2020). Entrepreneurial passion and entrepreneurial intention: The role of social support and entrepreneurial self-efficacy. Studies in Higher Education, 1-17. https://doi.org/10.1080/03075079.2020.1770716

Neneh, N. (2015). Entrepreneurial self-efficacy (ESE) and small business performance: The mediating effect of entrepreneurial mindset and openness to experience. Problems and Perspectives in Management, 13(4-1), 271-280.

Newman, A., Obschonka, M., Schwarz, S., Cohen, M., \& Nielsen, I. (2019). Entrepreneurial self-efficacy: A systematic review of the literature on its theoretical foundations, measurement, antecedents, and outcomes, and an agenda for future research. Journal of Vocational Behavior, 110(B), 403-419. https://doi.org/10.1016/j.jvb.2018.05.012

Norman, P., Conner, M. T., \& Stride, C. B. (2012). Reasons for binge drinking among undergraduate students: An application of behavioural reasoning theory. British Journal of Health Psychology, 17(4), 682-698. https://doi. org/10.1111/j.2044-8287.2012.02065.x

Nsahlai, V. K., Zogli L. J, Lawa E., \& Dlamini B. I. (2020). Factors influencing entrepreneurial intention: A case of students in a South African university. Academy of Entrepreneurship Journal, 26(1). https://www.abacademies. org/articles/Factors-influencing-entrepreneurial-intention-a-case-ofstudents-in-a-South-African-university-1528-2686-26-1-317.pdf

Obschonka, S., \& Rodermund, E. (2010). Entrepreneurial intention as developmental outcome. Journal of Vocational Behavior, 77(1), 63-72. http://dx.doi.org/10.1016/j.jvb.2010.02.008

Omar, N.A., Shah, N.U., Hasan, N.A., \& Ali, M.H. (2019). The influence of selfefficacy, motivation, and independence on students' entrepreneurial intentions. Journal of Nusantara Studies, 4(2) 1-28. https://doi. org/10.24200/jonus.vol4iss2pp1-28

Paez, D., \& García, J. (2011). Acercamiento a las características del universitario emprendedor en la Unidad de Emprendimiento de la Universidad Nacional de Colombia. Revista Escuela de Administración y Negocios, 71, 52-69. http://journal.ean. edu.co/index.php/Revista/article/view/551

Pabon, R. M. (2011). Estudio de actitudes emprendedoras con profesionales que crearon empresa. Revista Escuela de Administración de Negocios, 71, 70-83. Retrieved from http://journal.ean.edu.co/index.php/Revista/ article/view/552

Peng, Z., Lu, G., \& Kang, H. (2012). Entrepreneurial intentions and its influencing factors: A survey of the university students in Xi'an China. Creative Education, 3, 95-100. http://dx.doi.org/ 10.4236/ce.2012.38B021

Pfeifer, S., Šarlija, N., \& Zekic Sušac, M. (2014). Shaping the entrepreneurial mindset: Entrepreneurial intentions of business students in Croatia. Journal of Small Business Management, 54(1), 102-117. https://doi. org $/ 10.1111 / \mathrm{jsbm} .12133$ 
Phipps, S. T., \& Prieto, L. C. (2015). Women versus men in entrepreneurship: A comparison of the sexes on creativity, political skill, and entrepreneurial intentions. Academy of Entrepreneurship Journal, 21(1), 32-43. https:// www.abacademies.org/articles/aejvol21no12015.pdf

Pihie, Z., \& Bagneri, A. (2013). Self-efficacy and entrepreneurial intention: The mediation effect of self-regulation. Vocations and Learning, 6(3), 385-401. http://dx.doi.org/10.1007/s12186-013-9101-9

Podsakoff, P.M., Mackenzie, S.B., \& Podsakoff, N.P. (2012) Sources of method bias in social science research and recommendations on how to control it. Annual Review of Psychology, 63(1), 539-569. http://dx.doi.org/10.1146/ annurev-psych-120710-100452

Prabhu, V., McGuire, S., Drost, E., \& Kwong, K. (2012). Proactive personality and entrepreneurial intent: Is entrepreneurial self-efficacy a mediator or moderator? International Journal of Entrepreneurial Behavior \& Research, 18(5), 559-586. https://doi.org/10.1108/13552551211253937

Ryan, J., \& Casidy, R. (2018). The role of brand reputation in organic food consumption: A behavioral reasoning perspective. Journal of Retailing and Consumer Services, 41, 239-247. https://doi.org/10.1016/j. jretconser.2018.01.002

Saeed, S., Yousafzai, Y., Yani-De-Soriano, M., \& Muffatto, M. (2015). The role of perceived university support in the formation of students' entrepreneurial intention. Journal of Small Business Management, 53(4), 1127-1145. https://doi.org/10.1111/jsbm.12090

Sanchez, J. C. (2013). The impact of an entrepreneurship education program on entrepreneurial competencies and intention. Journal of Small Business Management, 51(3), 447-465. https://doi.org/10.1111/jsbm.12025

Setiawan, J. L. (2013). Examining entrepreneurial self-efficacy among students. The 5th Indonesia International Conference on Innovation, Entrepreneurship, and Small Business (IICIES 2013), 115, 235-242. https://doi.org/10.1016/j.sbspro.2014.02.431

Shahab, Y., Chengang, Y., Arbizu, A. D., \& Haider, M. J. (2018). Entrepreneurial self-efficacy and intention: Do entrepreneurial creativity and education matter? International Journal of Entrepreneurial Behavior \& Research, 25(2), 259-280. https://doi.org/10.1108/ijebr-12-2017-0522

Shava, H., \& Chinyamurindi, W. T., (2019). The influence of economic motivation, desire for independence and self-efficacy on willingness to become an entrepreneur. Southern African Journal of Entrepreneurship and Small Business Management, 11(1), 1-12. htttps://doi.org/10.4102/ sajesbm.v11i1.234

Shinnar, S., Hsu, K., \& Powell, B. (2014). Self-efficacy, entrepreneurial intentions, and gender: Assessing the impact of entrepreneurship education longitudinally. The International Journal of Management Education, 12(3), 561-570. http://dx.doi.org/10.1016/j.ijme.2014.09.005 Shmueli, G., Sarstedt, M., Hair, J.F., Cheah, J. H., Ting, H., Vaithilingam, S., \& Ringle, C.M. (2019). Predictive model assessment in PLS-SEM: Guidelines 
for using PLSpredict. European Journal of Marketing, 53(11), 2322-2347. https://doi.org/10.1108/EJM-02-2019-0189

Singelis, T. M. (1994). The measurement of independent and interdependent self-construals. Personality and Social Psychology Bulletin, 20, 580-591. https://doi.org/10.1177/0146167294205014

Solesvik, M., Westhead, P., Kolvereid, L., \& Matlay, H. (2012). Student intentions to become self-employed: The Ukrainian context. Journal of Small Business and Enterprise Development, 19(3), 441-460. http:// dx.doi.org/10.1108/14626001211250153

Solesvik, M. Z. (2013). Entrepreneurial motivations and intentions: investigating the role of education major. Education + Training, 55(3), 253-271. https://doi.org/10.1108/00400911311309314

Soria-Barreto, K., Zuniga-Jara, S., \& Ruiz-Campo, S. (2016). Education and entrepreneurial intent in university students: $A$ case study. University Training, 9(1), 25-34. https://doi.org/10.4067/s071850062016000100004

Staniewski, M., \& Awruk, K. (2015). Motivating factors and barriers in the commencement of one's own business for potential entrepreneurs. Economic Research-Ekonomska Istraživanja, 28(1), 583-592. https://doi. org/10.1080/1331677x.2015.1083876

Torres, J., \& Watson, W. (2013). An examination of the relationship between manager self-efficacy and entrepreneurial intentions and performance in Mexican small businesses. Contaduría y Administración, 58(3), 65-87. https://doi.org/10.1016/S0186-1042(13)71222-1

Tsai, K., Chang, H., \& Peng, C. (2016). Extending the link between entrepreneurial self-efficacy and intention: $A$ moderated mediation model. International Entrepreneurship and Management Journal, 12, 445-463. https://doi.org/10.1007/s11365-014-0351-2

Tyszka, T., Cieślik, J., Domurat, A., \& Macko, A. (2011). Motivation, self-efficacy, and risk attitudes among entrepreneurs during transition to a market economy. The Journal of Socio-Economics, 40(2), 124-131. https://doi. org/10.1016/j.socec.2011.01.011

Urbano, D., \& Aparicio, S. (2016). Entrepreneurship capital types and economic growth: International evidence. Technological Forecasting and Social Change, 102, 34-44. https://doi.org/10.1016/j.techfore.2015.02.018

Valencia, A., Montoya, I., \& Montoya, A., (2015). Factores explicativos de las intenciones emprendedoras en estudiantes universitarios. Revista Espacios, 36(5), 7-15. http://www.revistaespacios.com/ a15v36n05/15360507.html

Vanevenhoven, J., \& Liguori, E. (2016). The impact of entrepreneurship education. Journal of Small Business Management, 51(3), 315-328. https://doi.org/10.1111/jsbm.12026

Verheul, I., Thurik, R., Hessels, J., \& van der Zwan, P. (2010). Factors influencing the entrepreneurial engagement of opportunity and necessity 
entrepreneurs. Zoetermeer: Scientific Analyses Entrepreneurship and SMEs, 1-24. https://ondernemerschap.panteia.nl/pdf-ez/h201011.pdf

Walter, S. G., \& Block, J. H. (2016). Outcomes of entrepreneurship education: An institutional perspective. Journal of Business Venturing, 31(2), 216233. htttps://doi.org/10.1016/j.jbusvent.2015.10.003

Wang, L. Y., \& Huang, J. H (2019). Effect of entrepreneurial self-efficacy on the entrepreneurial intentions of students at a university in Hainan province in China: Taking social support as a moderator. International Journal of Learning, Teaching and Educational, 18(9), 183-200. https:// doi.org/10.26803/ijlter.18.9.10

Westaby, J. D. (2005). Behavioral reasoning theory: Identifying new linkages underlying intentions and behavior. Organizational Behavior and Human Decision Processes, 98(2), 97-120. https://doi.org/10.1016/j. obhdp.2005.07.003

Westaby, J. D., Probst, T. M., \& Lee, B. C. (2010). Leadership decision-making: A behavioral reasoning theory analysis. The Leadership Quarterly, 21(3), 481-495. https://psycnet.apa.org/doi/10.1016/j.leaqua.2010.03.011

Yurtkoru, E. S., Acar, P., \& Teraman, B. S. (2014). Willingness to take risk and entrepreneurial intention of university students: An empirical study comparing private and state universities. Procedia - Social and Behavioral Science, 150, 834-840. https://doi.org/10.1016/j.sbspro.2 014.09.092

Zhao, H., Seibert, S. E., \& Hills, G. E. (2005). The mediating role of selfefficacy in the development of entrepreneurial intentions. Journal of Applied Psychology, 90(6), 1265-1272. https://doi.org/10.1037/00219010.90.6.1265

Zhao, H., Seibert, S., \& Hills, G. (2005). The mediating role of self-efficacy in the development of entrepreneurial intentions. Journal of Applied Psychology, 90(6), 1265-1272. https://doi.org/10.1037/00219010.90.6.1265

\begin{abstract}
Abstrakt
CEL: Artykuł koncentruje się na ocenie bezpośredniego wpływu przedsiębiorczego poczucia własnej skuteczności i przedsiębiorczej intencji oraz pośredniego wpływu potrzeby niezależności na relacje między konstruktami. Pomimo wzmożonych wysiłków zmierzajq̨cych do kierowania zainteresowania młodych absolwentów przedsięwzięciem przedsiębiorczym, odsetek odpowiedzi był raczej mało imponujqcy i zniechęcajacy, co wymagało uwzględnienia, jakie czynniki mogq skłaniać absolwentów w Nigerii do podjęcia decyzji o przedsięwzięciu biznesowym. METODYKA: W badaniu przyjęto podejście ilościowe i zestaw danych od 235 absolwentów. Dane zostały przeanalizowane przy użyciu modeli czq̨stkowych najmniejszych kwadratów oraz równań strukturalnych (PLS-SEM). WYNIKI: Stwierdzono, że poczucie własnej skuteczności nie wpływa znaczq̨co na intencje przedsiębiorcze. Stwierdzono również, że potrzeba niezależności wpływa na intencje przedsiębiorcze. Badanie wykazało, że potrzeba niezależności w pełni pośredniczy w zwiq̨zku między przedsiębiorczym poczuciem własnej
\end{abstract}


skuteczności a przedsiębiorczym zamiarem. IMPLIKACJE TEORETYCZNE I PRAKTYCZNE: Ten artykuł zapewnia nowy wglad $w$ teorię rozumowania behawioralnego, poprzez jej zastosowanie w wyjaśnianiu poznawczej roli potrzeby niezależności w podejmowaniu decyzji, przy użyciu próbek z rozwijajq̨cej się gospodarki. ORYGINALNOŚĆ I WARTOŚĆ: Badanie rozwija nowe spojrzenie na czynniki podkreślajqce, które odpowiadajq za intencję przedsiębiorcy, aby rozpoczqć przedsięwzięcie biznesowe, zwłaszcza wśród młodych absolwentów w Nigerii, przez pryzmat teorii rozumowania behawioralnego. Ponadto popieramy zastosowanie tej teorii w literaturze dotyczqcej przedsiębiorczości, biorq̨ pod uwagę niedostatek badań, w których przyjęto tę teorię. Słowa kluczowe: poczucie własnej skuteczności, intencje przedsiębiorcze, niezależność, wiara w siebie, PLS-SEM.

\section{Biographical notes}

Victor Osadolor is a lecturer at Edo State University lyamu and seasoned scholar whose area of interest is entrepreneurship. He is currently a Ph.D. student at the University of Nigeria, Enugu Campus. He has traveled to several countries, presenting papers in both local and international conferences and has distinguished himself with scholarly works.

Dr. Emmanuel K. Agbaeze is a professor of Entrepreneurship with over twenty-seven years as an academic. He has traveled to several countries, presenting papers in both local and international conferences and has distinguished himself with scholarly works.

Ejikeme Emmanuel Isichei is a lecturer in the Department of Business Administration, Federal University Wukari, Taraba State, Nigeria. He is a doctoral candidate in the Department of Management, University of Nigeria, Enugu Campus. His research interests are entrepreneurship and strategic management.

Samuel Taiwo Olabosinde is a lecturer in the Department of Business Administration, Federal University Wukari, Taraba State, Nigeria. His research interests are supply chain management, Logistics, and transport management.

\section{Conflicts of interest}

The authors declare no conflict of interest. 


\section{Citation (APA Style)}

Osadolor, V., Agbaeze, E.K., Isichei, E.E., \& Olabosinde, S.T. (2021). Entrepreneurial self-efficacy and entrepreneurial intention: The mediating role of the need for independence. Journal of Entrepreneurship, Management, and Innovation, 17(4), 91-119. https://doi.org/10.7341/20211744 